\title{
Investigation of the Total Phenolic Content and Antioxidant Capacity of Three Sweet Pepper Cultivars (Capsicum annuum L.) at Different Development and Maturation Stages
}

\author{
Theodoros Papathanasiou1', Nikolaos Gougoulias', Vayos G. Karayannis ${ }^{2 *}$, \\ Christina-Anna Kamvoukou ${ }^{3}$

\begin{abstract}
${ }^{1}$ Department of Agriculture-Agrotechnology, School of Agricultural Sciences, University of Thessaly, 41500 Larissa, Gaiopolis Campus, Peripheral Road Larissa-Trikala, Greece

2 Department of Chemical Engineering, School of Engineering, University of Western Macedonia, 50100 Kozani, Koila, Greece

${ }^{3}$ School of Pharmacy, Aristotle University of Thessaloniki, 54124 Thessaloniki, University Campus, Greece

* Corresponding author, e-mail: vkarayannis@uowm.gr
\end{abstract}

Received: 10 January 2020, Accepted: 03 April 2020, Published online: 24 August 2020

\begin{abstract}
The aim of the current research was to investigate and compare the total phenolic content and antioxidant capacity of sweet pepper cultivars at different development and maturation stages, in order to optimize the beneficial effects. For that purpose, three important sweet pepper cultivars, namely Dolmy-F1, Yahoo-F1 and Florinis-NS-700, were cultivated in a greenhouse. Their total phenolic content, ascorbic acid content and antioxidant properties were assessed at different development and maturation stages. In the aforementioned cultivars, the total phenolic content ranged from 345.2 to $602.1,404.9$ to 794.5 , and 795.7 to $2220.3 \mu \mathrm{g}$ GAE g ${ }^{-1}$ FW respectively. The ascorbic acid content ranged from 236 to 957, 258 to 1157, and 410 to $1550 \mu \mathrm{g} \mathrm{AA} \mathrm{g}^{-1}$ FW respectively. The highest antioxidant activity was noted at the red maturity stage. Particularly the cultivar Florinis NS 700 was found to possess higher total phenolic, flavonoid phenol, non-flavonoid phenol, ascorbic acid contents, and greater antioxidant capacity, compared to the other cultivars. The results of our study recommend the consumption of the sweet peppers at red maturity stage, for achieving the maximum health-beneficial effects. Keywords
\end{abstract}

antioxidant capacity, total phenolic content, phenolic fractions, pepper cultivars, maturation stages

\section{Introduction}

Pepper (Capsicum annuum L.) is used as food and as spice due to its dietary and nutritional value. Pepper fruits are a natural reservoir of phenolic compounds (derivatives of cinnamic acid and flavonoid compounds), of vitamins (C and E), of provitamin A, and of the carotenoid compounds, which exercise strong antioxidant properties [1-4].

The free radicals are powerful oxidizers, which are formed during the normal metabolism of the aerobic cells, while damaging the basic biological molecules, ultimately causing the occurrence of many diseases in the human organism [5-7]. The oxidative destruction of the biomolecules can be protected, both with endogenous and dietary antioxidants [8-11].

Phenolic compounds are synthesized by plants during their adaptation to various biotic and abiotic stresses. Some of these compounds (secondary metabolites) contribute to shaping of the taste and color of fruits and plants, while others protect the plants from the herbivores and the pathogenic microbes [12-14]. Phenolic compounds are powerful antioxidants, which can protect the human organism from free radicals $[15,16]$. It has been documented that antiradical activity is related to substitution of hydroxyl groups in the aromatic rings of phenols [17, 18]. Phenolic compounds cannot be produced by the human organism and are taken in mainly through the diet. Epidemiological investigations demonstrate that the intake of polyphenols with food reduces the risk of cardiovascular disease, cancer and other diseases [19, 20].

The phenolic content and the antioxidant properties of pepper fruits are influenced by the cultivation systems, development and maturing stage, fertilization, irrigation and cultivar [21, 22]. Plant growth and yield can be adversely affected by an increased salinity of irrigation water Electrical Conductivity (EC) $\geq 3 \mathrm{dS} \mathrm{m}^{-1}[23]$. 
Some authors reported that the detrimental impact of salinity mainly affects fruits rather than leaves and stems [24]. According to Navarro et al. [25], salt (15 mM NaCl added to the base nutrient solution) decreased the ascorbic acid content of pepper fruits during the green maturation stage.

Some authors studied the effect of the type of fertilization (mineral and combined with compost) in the yellow Cazzone pepper (Capsicum annuum L.) at two stages of maturity on the phenolic content. In particular, it was reported that the increase of the degree of maturation showed higher phenolic content in the yellow pepper fertilized with the combined treatment compared to mineral fertilization [26, 27].

Although there are studies on the polyphenols content, the vitamin $\mathrm{C}$ (ascorbic acid) content and antioxidant properties generally of pepper cultivars, there are very limited reports particularly for the sweet pepper cultivars grown in Greece. Therefore, the investigation of these vegetable is required due to their significant functional and nutritional value.

The objective of the present study is to investigate and compare the polyphenols content, the vitamin $\mathrm{C}$ content, and the antioxidant capacity of sweet pepper cultivars grown in Greece, at different development and maturation stages for optimizing their beneficial effects for human health. In this regard, three hybrids of sweet pepper that are cultivated in Greece, and which are very important for domestic consumption, were chosen for this study.

\section{Materials and methods}

\subsection{Experimental}

Pepper plants (Capsicum annuum) were obtained from a commercial nursery of Larissa, Greece and cultivated in the greenhouse of the University of Thessaly, Larissa, Greece, from 20 February 2017 to 30 July 2017 in an area of $100 \mathrm{~m}^{2}$ ( $33 \mathrm{~m}^{2}$ for each cultivar with 80 plants). Three hybrids of sweet pepper were cultivated, the distance between adjacent plants in the rows was $0.5 \mathrm{~m}$ and between rows was $0.8 \mathrm{~m}$. Each treatment included 20 plants and 4 replications. The basic characteristics for each cultivar are presented in Table 1. During the experiment, $30 \mathrm{~kg}$ of fungicide BORD $20 \mathrm{WP}, 200 \mathrm{~kg}$ nitrogen, $50 \mathrm{~kg}$ phosphorus, $200 \mathrm{~kg}$ potassium and $50 \mathrm{~kg}$ calcium per hectare, were added. Also, $5000 \mathrm{~m}^{3}$ irrigation water per hectare were applied. The EC of the water was equal to $0.51 \mathrm{dS} \mathrm{m}^{-1}$.

Harvest was carried out at three development stages and at three maturation stages of the fruits (Table 2). For each treatment four pepper fruits with uniform size, shape and color were harvested for analysis.
Table 1 Basic characteristics of the pepper fruits

\begin{tabular}{lccccc}
\hline $\begin{array}{l}\text { Hybrid } \\
\text { varieties }\end{array}$ & Origin & Taste & Shape & $\begin{array}{c}\text { Flesh } \\
\text { thickness }\end{array}$ & $\begin{array}{c}\text { Color of } \\
\text { commercial } \\
\text { acceptability }\end{array}$ \\
\hline Dolmy F1 & Holland & Sweet & Bell & $\begin{array}{c}\text { Thick } \\
\text { flesh }\end{array}$ & Light green \\
Yahoo F1 & Italy & Sweet & Oblong & $\begin{array}{c}\text { Thick } \\
\text { flesh }\end{array}$ & Light green \\
$\begin{array}{l}\text { Florinis } \\
\text { NS 700 }\end{array}$ & Greece & Sweet & Oblong & $\begin{array}{c}\text { Thick } \\
\text { flesh }\end{array}$ & Deep-red \\
\hline
\end{tabular}

Table 2 Development and maturation stages of the pepper fruits during the growing period

\begin{tabular}{lcccc}
\hline Stages & $\begin{array}{c}\text { Days after } \\
\text { flowering }\end{array}$ & Dolmy F1 & Yahoo F1 & $\begin{array}{c}\text { Florinis NS } \\
700\end{array}$ \\
\hline \multicolumn{2}{c}{ Development } & & Fruit size & \\
S1 & 10 & Small & Small & Small \\
S2 & 30 & Medium & Medium & Medium \\
S3 & 40 & Large & Large & Large \\
\hline Maturation & & Color & \\
S4 & 50 & Dark green & Dark green & Dark green \\
S5 & 60 & Light green & Light green & Green with \\
brown
\end{tabular}

\subsection{Analytical methods}

\subsubsection{Soil analysis}

Soil sampling was performed at $0-20 \mathrm{~cm}$ depth before transplanting and at the end of the growing period for each experimental site of each cultivar. Each sampling was replicated four times within each experimental site. Soil was analyzed using the following methods that were referred by Page [28]. Organic matter was analyzed by chemical oxidation with $1 \mathrm{~mol} \mathrm{~L}^{-1} \mathrm{~K}_{2} \mathrm{Cr}_{2} \mathrm{O}_{7}$ and titration of the remaining reagent with $0.5 \mathrm{~mol} \mathrm{~L}^{-1} \mathrm{FeSO}_{4}$. The $\mathrm{pH}$ and Electrical Conductivity were measured in the extract (1 part soil: 5 parts $\mathrm{H}_{2} \mathrm{O}$ ). Inorganic nitrogen was extracted with $0.5 \mathrm{~mol} \mathrm{~L}^{-1} \mathrm{CaCl}_{2}$ and estimated by distillation in the presence of $\mathrm{MgO}$ and Devarda's alloy, respectively. Available P forms (Olsen P) were extracted with $0.5 \mathrm{~mol} \mathrm{~L}^{-1} \mathrm{NaHCO}_{3}$ and measured by spectroscopy. Exchangeable form of potassium was extracted with $1 \mathrm{~mol} \mathrm{~L}^{-1} \mathrm{CH}_{3} \mathrm{COONH}_{4}$ and measured by flame photometer (Essex, UK). Available forms of $\mathrm{Mn}, \mathrm{Zn}$, and $\mathrm{Cu}$ were extracted with DTPA (diethylene triamine pentaacetic acid $0.005 \mathrm{~mol} \mathrm{~L}^{-1}+\mathrm{CaCl}_{2} 0.01 \mathrm{~mol} \mathrm{~L}^{-1}+$ triethanolamine $0.1 \mathrm{~mol} \mathrm{~L}^{-1}$ ) and measured by atomic absorption. The samples were analyzed by atomic absorption (Spectroscopy Varian Spectra AA 10 plus, Victoria, Australia) using flame and air-acetylene mixture [29]. 
The bulk density was calculated using a hydraulic undisturbed soil core sampler of $45 \mathrm{~mm}$ diameter. The sample was weighted and dried in an oven at $100{ }^{\circ} \mathrm{C}$ for 24 hours. The results were expressed in dry soil $\mathrm{g} \mathrm{cm}^{-3}$ of the total undisturbed soil volume.

The nutrient concentrations of the soil were transformed to nutrient contents based on Eq. (1):

Nutrient content $\left(\mathrm{kg} \mathrm{ha}^{-1}\right)$

$=$ Nutrient concentration $\left(\mathrm{kg} 10^{-6} \mathrm{~kg}^{-1}\right)$

$\times 1300\left(\mathrm{~kg} \mathrm{~m}^{-3}\right) \times 104\left(\mathrm{~m}^{2} \mathrm{ha}^{-1}\right) \times 0.2(\mathrm{~m})$,

where $1300 \mathrm{~kg} \mathrm{~m}^{-3}$ is the soil bulk density value.

Soil Exchangeable Sodium Percent (ESP) was determined according to Eq. (2):

$\mathrm{ESP}=(\mathrm{Na}+/ \mathrm{CEC}) \times 100$,

where:

- $\mathrm{ESP}=$ Exchangeable Sodium Percentage (\%)

- $\mathrm{Na}^{+}=$Measured exchangeable $\mathrm{Na}\left(\mathrm{cmol} \mathrm{kg}^{-1}\right)$

- $\mathrm{CEC}=$ Cation Exchange Capacity $\left(\mathrm{cmol} \mathrm{kg}^{-1}\right)$

\subsubsection{Element analysis of pepper leaves}

Four randomly chosen plants were included for each experimental site of each cultivar. From each plant, five newer fully developed leaves were collected at the $82^{\text {nd }}$ day from the start of the growing period. Namely, each treatment included collection of 20 leaves. The experiment included four replications. Dried samples of leaves were ground in a rotor mill to $<300 \mu \mathrm{m}$ prior the analysis. Total nitrogen content in leaves was measured using the Kjeldhal method described by Jones [30], while the total phosphorus and potassium contents were determined by dry combustion according to the methods described by Jones and Case [31].

\subsubsection{Preparation of pepper extracts}

$10 \mathrm{~g}$ of the pepper samples was extracted two times by $20 \mathrm{~mL}$ of $80 \%$ aqueous ethanol. Specifically, samples were incubated for $24 \mathrm{~h}$ in the extractant at stirring. The supernatant material was gathered in a $50 \mathrm{~mL}$ volumetric flask. The pellet was re-treated with aqueous ethanol for 2 hours at stirring at room temperature. The extract was gathered after centrifugation/filtration in the same volumetric flask and the volume was made up to $50 \mathrm{~mL}$ with aqueous ethanol and used for further chemical analysis [32].

\subsubsection{Pepper fruit analysis}

Total phenolic (TP) content was determined with the Folin-Ciocalteu (F-C) reagent [33] according to the method by Singleton and Rossi [34] using the microvariant proposed by Baderschneider et al. [35] and the results were expressed as Gallic Acid Equivalent (GAE) in $\mu \mathrm{g} \mathrm{g}^{-1} \mathrm{FW}$. Nonflavonoid phenol (NFP) content was determined with the F-C reagent after removing the flavonoid phenol (FP) with formaldehyde according to the method by [36] and was expressed as GAE in $\mu \mathrm{g} \mathrm{g}^{-1} \mathrm{FW}$. FP were determined as a difference between the content of TP and NFP. Their amount was evaluated as GAE in $\mu \mathrm{g} \mathrm{g}^{-1} \mathrm{FW}$.

Ascorbic acid (AA) was determined according to 2.6 dichlorophenolindophenol dye method as described by Deepa et al. [37] with some modifications. Fresh samples $(10 \mathrm{~g})$ were homogenized for $5 \mathrm{~min}$ with $10 \mathrm{~mL}$ of $3 \%$ metaphosphoric acid (w/v) using mortar and pestle. The homogenized mixtures were centrifuged at 4,000 $\mathrm{Xg}$ for $5 \mathrm{~min}$ at room temperature. After filtration, the volume of extract was made up to $100 \mathrm{~mL}$ with $3 \%$ metaphosphoric acid (w/v). $10 \mathrm{~mL}$ of extract were titrated against standard 2,6-dichlorophenolindophenol dye, which was already been standardized against standard ascorbic acid. Results were expressed as $\mu \mathrm{g} \mathrm{g}^{-1} \mathrm{FW}$.

The antiradical activity of the ethanol extracts was determined according to the method by Brand-Williams et al. [38] using the stable free radical 2,2'-diphenyl-1-picrylhydrazyl (DPPH) and was expressed as Trolox (synthetic vitamin E) equivalent in $\mu \mathrm{mol} 100 \mathrm{~g}^{-1} \mathrm{FW}$.

The inhibition coefficient $\left(\mathrm{IC}_{50}\right)$, represents $50 \%$ reduction in the color intensity of the radical DPPH by the total phenols $\left(\mu \mathrm{g} \mathrm{mL}^{-1}\right)$ in the studied extracts and was determined by plotting the dependence of the TP content on the bleaching of DPPH solutions. The $\mathrm{IC}_{50}$ corresponds in the higher antioxidant capacity.

The percentage of inhibition was calculated by the following Eq. (3):

$\%$ inhibition DPPH $=\frac{E_{0}-E_{x}}{E_{0}} \times 100$,

where $E_{0}$ is the extinction of the radical solution before the reaction, and $E_{x}-$ after polyphenol addition [39].

\subsubsection{Statistical analysis}

Data were analyzed using the MINITAB [40] statistical package. The experiment had four replications. Analysis of variance was used to assess treatment effects. Mean separation was made using Tukey's test when significant differences $(\mathrm{P}=0.05)$ between treatments were found. Correlation and regression analyses between TP, NFP, FP, AA contents and DPPH was conducted using the same statistical package and quantified in terms of the correlation 
factor, $R^{2}$. All presented numeric values are means of four measurements \pm standard deviation (SD).

\section{Results and discussion}

The soil of experiment before the start of crop at depth 0-20 cm was characterized as sandy loam (SL) (Table 3). The $\mathrm{pH}$ at (1:5) soil/water extract was 7.70, while the EC measured in the same extract was $0.52 \mathrm{dS} \mathrm{m}^{-1}$, organic matter and $\mathrm{CaCO}_{3}$ soil content was $2.31 \%$ and $4.20 \%$, respectively. Moreover, the exchangeable $\mathrm{Na}$ content and the CEC of soil were $276.7 \mathrm{mg} \mathrm{kg}^{-1}$ and $23.9 \mathrm{cmol} \mathrm{kg}^{-1}$ respectively. The ESP was $5.0 \%$ and there is no risk sodic soil. Also, the available forms of $\mathrm{N}, \mathrm{K}$ and $\mathrm{P}$ at the end of the growing season decreased compared to the start of the growing season (Table 4). The decrease observed was higher in the available form of $\mathrm{K}$ and lower in the available form of $\mathrm{P}$. The reduction in the amount of the available forms of micronutrients and macronutrients elements, after the end of the growing season, was possibly due to uptake by the plant and rinsing on lower layers of soil.

Also, the analysis of plant tissues, in the newer fully developed leaves at the $82^{\text {nd }}$ day from the start of the growing period, showed satisfactory macronutrient levels in the leaves (Table 5).

Inorganic $\mathrm{N}, \mathrm{P}_{2} \mathrm{O}_{5}$, and $\mathrm{K}_{2} \mathrm{O}$ concentrations of the soil at the start and at the end of the growing period were transformed to nutrient contents, and are presented in Table 6.

Table 3 Soil chemical properties at the start and at the end of the growing period

\begin{tabular}{|c|c|c|}
\hline \multirow[t]{2}{*}{ Property } & $\begin{array}{c}\text { Start of growing } \\
\text { period }\end{array}$ & $\begin{array}{c}\text { End of growing } \\
\text { period }\end{array}$ \\
\hline & \multicolumn{2}{|c|}{ Soil depth $(0-20) \mathrm{cm}$} \\
\hline Texture & Sandy Loam (SL) & Sandy Loam (SL) \\
\hline$* \mathrm{pH}$ & $7.70 \pm 0.43$ & $7.42 \pm 0.40$ \\
\hline$* * \mathrm{EC}\left(\mathrm{dS} \mathrm{m}^{-1}\right)$ & $0.52 \pm 0.04$ & $0.36 \pm 0.03$ \\
\hline $\mathrm{CaCO}_{3}(\%)$ & $4.20 \pm 0.27$ & $3.90 \pm 0.23$ \\
\hline Organic matter $(\%)$ & $2.31 \pm 0.16$ & $1.84 \pm 0.11$ \\
\hline N-total ( $\left.\mathrm{g} \mathrm{kg}^{-1}\right)$ & $1.12 \pm 0.09$ & $0.98 \pm 0.08$ \\
\hline Na-exchangeable $\left(\mathrm{mg} \mathrm{kg}^{-1}\right)$ & $276.7 \pm 19.45$ & $164.2 \pm 13.14$ \\
\hline$* * * \mathrm{CEC}\left(\mathrm{cmol} \mathrm{kg}^{-1}\right)$ & $23.93 \pm 1.33$ & $19.10 \pm 1.47$ \\
\hline Cu-DTPA ( $\left.\mathrm{mg} \mathrm{kg}^{-1}\right)$ & $2.52 \pm 0.21$ & $1.98 \pm 0.15$ \\
\hline Zn-DTPA ( $\left.\mathrm{mg} \mathrm{kg}^{-1}\right)$ & $3.88 \pm 0.22$ & $2.15 \pm 0.18$ \\
\hline Mn-DTPA ( $\left.\mathrm{mg} \mathrm{kg}^{-1}\right)$ & $13.00 \pm 1.11$ & $10.20 \pm 0.98$ \\
\hline Fe-DTPA $\left(\mathrm{mg} \mathrm{kg}^{-1}\right)$ & $2.23 \pm 0.16$ & $1.53 \pm 0.14$ \\
\hline
\end{tabular}

* pH and **Electrical Conductivity (EC) measured in the extract (1 part soil:5 parts $\left.\mathrm{H}_{2} \mathrm{O}\right)$; ${ }^{* * *}$ CEC, Cation Exchange Capacity; Start of growing period, data represent average means and SE deviation, $(n)=4$; End of growing period, data represent average means for all treatments and SE deviation, $(n)=9$.
Table 4 Soil nutrient elements at the start and at the end of the growing period

\begin{tabular}{lcc}
\hline *ES & Start of growing period & End of growing period \\
\hline \multirow{2}{*}{ Dolmy F1 } & $269.7 \pm 19.1$ & $196.7 \pm 12.3$ \\
Yahoo F1 & $269.7 \pm 19.1$ & $202.3 \pm 12.1$ \\
Florinis NS 700 & $269.7 \pm 19.1$ & $184.2 \pm 11.9$ \\
\hline & \multicolumn{1}{c}{ P-Olsen $\left(\mathrm{mg} \mathrm{kg}^{-1}\right.$ soil) } \\
Dolmy F1 & $22.3 \pm 1.2$ & $18.5 \pm 1.0$ \\
Yahoo F1 & $22.3 \pm 1.2$ & $19.2 \pm 1.4$ \\
Florinis NS 700 & $22.3 \pm 1.2$ & $17.5 \pm 1.0$ \\
\hline & K-exchangeable $\left(\mathrm{mg} \mathrm{kg}^{-1} \mathrm{soil}\right)$ \\
Dolmy F1 & $424.2 \pm 22.3$ & $336.2 \pm 16.0$ \\
Yahoo F1 & $424.2 \pm 22.3$ & $349.5 \pm 18.4$ \\
Florinis NS 700 & $424.2 \pm 22.3$ & $327.9 \pm 17.7$ \\
\hline
\end{tabular}

*ES-Experimental Sample; Results was determined at soil depth $0-20 \mathrm{~cm}$; Data represent average means and SE deviation, $(n)=4$.

Table 5 *Foliar analysis in pepper plants

\begin{tabular}{lccc}
\hline Hybrid varieties & $\mathrm{N}$ & $\mathrm{P}$ & $\mathrm{K}$ \\
\hline Dolmy F1 & & $\mathrm{g} 100 \mathrm{~g}^{-1} \mathrm{DW}$ & \\
Yahoo F1 & $2.92 \pm 0.23^{\mathrm{b}}$ & $0.32 \pm 0.03^{\mathrm{b}}$ & $2.78 \pm 0.18^{\mathrm{a}}$ \\
Florinis NS 700 & $3.64 \pm 0.25^{\mathrm{a}}$ & $0.48 \pm 0.04^{\mathrm{a}}$ & $2.98 \pm 0.21^{\mathrm{a}}$ \\
\hline
\end{tabular}

* $82^{\text {nd }}$ day from the start of the growing period; Data represent average means and SE deviation, $(n)=4$; For each chemical property of samples, the values in the columns of the table with the same letter among of $(\mathrm{a}, \mathrm{b}$ or $\mathrm{c})$ do not differ significantly according to the Tukey's test $(\mathrm{P}=0.05), n=4$.

Table 6 Balance of available mineral nutrient in the soil

\begin{tabular}{|c|c|c|c|}
\hline *ES & $\begin{array}{l}\text { Start of } \\
\text { growing } \\
\text { period }\end{array}$ & $\begin{array}{c}\text { Surface } \\
\text { fertilizer } \\
\text { application }\end{array}$ & $\begin{array}{l}\text { End of } \\
\text { growing } \\
\text { period }\end{array}$ \\
\hline & \multicolumn{3}{|c|}{ Mineral-N ( $\mathrm{kg} \mathrm{ha}^{-1}$ soil) } \\
\hline Dolmy F1 & $701.2 \pm 50.1$ & 200 & $511.4 \pm 32.0$ \\
\hline Yahoo F1 & $701.2 \pm 50.1$ & 200 & $526.0 \pm 32.9$ \\
\hline \multirow[t]{2}{*}{ Florinis NS 700} & $701.2 \pm 50.1$ & 200 & $478.9 \pm 30.9$ \\
\hline & \multicolumn{3}{|c|}{ Available- $\mathrm{P}_{2} \mathrm{O}_{5}\left(\mathrm{~kg} \mathrm{ha}^{-1}\right.$ soil $)$} \\
\hline Dolmy F1 & $132.8 \pm 7.0$ & 50 & $110.2 \pm 6.0$ \\
\hline Yahoo F1 & $132.8 \pm 7.0$ & 50 & $114.3 \pm 8.2$ \\
\hline \multirow[t]{2}{*}{ Florinis NS 700} & $132.8 \pm 7.0$ & 50 & $104.2 \pm 6.2$ \\
\hline & \multicolumn{3}{|c|}{ Available- $\mathrm{K}_{2} \mathrm{O}\left(\mathrm{kg} \mathrm{ha}^{-1}\right.$ soil $)$} \\
\hline Dolmy F1 & $1329.2 \pm 70.0$ & 200 & $1053.4 \pm 50.2$ \\
\hline Yahoo F1 & $1329.2 \pm 70.0$ & 200 & $1095.0 \pm 67.6$ \\
\hline Florinis NS 700 & $1329.2 \pm 70.0$ & 200 & $1027.4 \pm 55.5$ \\
\hline
\end{tabular}

*ES-Experimental Sample; Results were obtained at 0-20 cm soil depth; Data represent average means and SE deviation, $(n)=4$. 
Table 6 shows the balance of mineral nutrient elements in the soil at depth of $0-20 \mathrm{~cm}$, during the growing period. Our results confirm the high demands of the crop in available forms of $\mathrm{N}$ and $\mathrm{K}$ during the growing period.

Changes in TP, NFP, FP and AA contents of the sweet pepper hybrids at the examined development and maturation stages are presented in Table 7.

From Table 7, TP content in the cultivars Dolmy F1, Yahoo F1 and Florinis NS 700 during the development and maturation stages ranged from 345.2 to 602.1, 404.9 to 794.5 , and 795.7 to $2220.3 \mu \mathrm{g} \mathrm{GAE} \mathrm{g}^{-1} \mathrm{FW}$, respectively. TP content in the cultivars Yahoo F1 and Florinis NS 700 during development stages decreased progressively, while during the three maturation stages increased progressively (from the green to the red stage) by $90.4 \%$ and $143.4 \%$, respectively. Howard et al. [41] have reported that phenolic content change during maturation depends on the pepper cultivars. The cultivar Dolmy F1 after the development

Table 7 TP, NFP, FP and AA contents during development (S1-S3) and maturation (S4-S6) stages of the peppers

\begin{tabular}{|c|c|c|c|c|}
\hline \multirow[t]{2}{*}{$* \mathrm{~S}$} & $\mathrm{TP}$ & NFP & FP & AA \\
\hline & \multicolumn{3}{|c|}{$\mu \mathrm{g} \mathrm{GAE} \mathrm{g}^{-1} \mathrm{FW}$} & $\mu \mathrm{g} \mathrm{g}^{-1} \mathrm{FW}$ \\
\hline & \multicolumn{4}{|c|}{ Dolmy F1 } \\
\hline $\mathrm{S} 1$ & $563.4 \pm 33.1^{\mathrm{e}}$ & $194.4 \pm 14.9^{\mathrm{def}}$ & $369.0 \pm 27.6^{\mathrm{fg}}$ & $236.0 \pm 13.8^{j}$ \\
\hline S2 & $467.9 \pm 24.8^{\mathrm{g}}$ & $145.1 \pm 10.5^{\mathrm{fg}}$ & $322.9 \pm 24.4^{\mathrm{gh}}$ & $478.0 \pm 35.3^{\mathrm{hi}}$ \\
\hline S3 & $602.1 \pm 35.1^{\mathrm{e}}$ & $198.7 \pm 14.9^{\text {de }}$ & $403.4 \pm 26.1^{\mathrm{f}}$ & $762.0 \pm 36.6^{\mathrm{g}}$ \\
\hline S4 & $444.3 \pm 23.6^{\mathrm{gh}}$ & $142.2 \pm 10.5^{\mathrm{fg}}$ & $302.1 \pm 23.7^{g h i}$ & $957.0 \pm 40.7^{\mathrm{e}}$ \\
\hline S5 & $393.3 \pm 21.4^{\mathrm{hi}}$ & $114.1 \pm 9.9^{\mathrm{gh}}$ & $279.2 \pm 18.2^{\mathrm{hi}}$ & $872.0 \pm 39.4^{\mathrm{ef}}$ \\
\hline \multirow[t]{2}{*}{ S6 } & $345.2 \pm 19.3^{\mathrm{i}}$ & $96.7 \pm 8.7^{\mathrm{h}}$ & $248.5 \pm 16.7^{\mathrm{i}}$ & $896.0 \pm 40.2^{\mathrm{ef}}$ \\
\hline & \multicolumn{4}{|c|}{ Yahoo F1 } \\
\hline S1 & $794.5 \pm 35.6^{\mathrm{d}}$ & $278.1 \pm 17.2^{\mathrm{bc}}$ & $516.4 \pm 30.2^{\mathrm{e}}$ & $258.0 \pm 14.6^{j}$ \\
\hline $\mathrm{S} 2$ & $543.9 \pm 32.0^{\mathrm{ef}}$ & $190.4 \pm 14.1^{\mathrm{def}}$ & $353.5 \pm 26.4^{\mathrm{fg}}$ & $491.0 \pm 38.7^{\mathrm{hi}}$ \\
\hline S3 & $488.1 \pm 28.5^{\mathrm{fg}}$ & $161.1 \pm 13.0^{\mathrm{efg}}$ & $327.0 \pm 24.7^{\mathrm{gh}}$ & $859.0 \pm 37.8^{f}$ \\
\hline S4 & $404.9 \pm 22.2^{\mathrm{hi}}$ & $121.5 \pm 11.2^{\mathrm{gh}}$ & $283.4 \pm 18.9^{\text {hi }}$ & $1157.0 \pm 52.0^{\mathrm{c}}$ \\
\hline S5 & $454.8 \pm 24.4^{g}$ & $150.1 \pm 11.2^{\mathrm{fg}}$ & $304.7 \pm 24.0^{\mathrm{ghi}}$ & $1046.0 \pm 44.7^{\mathrm{d}}$ \\
\hline \multirow[t]{2}{*}{ S6 } & $771.1 \pm 34.9^{\mathrm{d}}$ & $215.9 \pm 18.0^{\text {de }}$ & $555.2 \pm 32.4^{\mathrm{de}}$ & $1150.0 \pm 51.9^{\mathrm{c}}$ \\
\hline & \multicolumn{4}{|c|}{ Florinis NS 700} \\
\hline $\mathrm{S} 1$ & $907.4 \pm 40.7^{\mathrm{c}}$ & $344.8 \pm 21.5^{\mathrm{b}}$ & $562.6 \pm 33.9^{\mathrm{de}}$ & $410.0 \pm 33.1^{\mathrm{i}}$ \\
\hline S2 & $957.2 \pm 44.9^{c}$ & $335.0 \pm 18.5^{\mathrm{b}}$ & $622.2 \pm 38.4^{\mathrm{cd}}$ & $540.0 \pm 32.1^{\mathrm{h}}$ \\
\hline S3 & $795.7 \pm 35.5^{\mathrm{d}}$ & $302.4 \pm 17.9^{\mathrm{b}}$ & $493.3 \pm 28.8^{\mathrm{e}}$ & $900.0 \pm 40.4^{\mathrm{ef}}$ \\
\hline S4 & $913.3 \pm 42.7^{\mathrm{c}}$ & $255.7 \pm 19.3^{\mathrm{cd}}$ & $657.6 \pm 39.6^{c}$ & $1200.0 \pm 52.9^{\mathrm{bc}}$ \\
\hline S5 & $2009.4 \pm 89.2^{b}$ & $462.1 \pm 23.9^{\mathrm{a}}$ & $1547.3 \pm 65.3^{b}$ & $1278.0 \pm 58.1^{\mathrm{b}}$ \\
\hline S6 & $2220.3 \pm 99.9^{\mathrm{a}}$ & $466.3 \pm 24.1^{\mathrm{a}}$ & $1754.0 \pm 74.9^{\mathrm{a}}$ & $1550.0 \pm 87.6^{\mathrm{a}}$ \\
\hline
\end{tabular}

*S, Development and maturation stages of the sweet pepper fruits; S1, small green; S2, medium green; S3, large green; S4, dark green mature; S5, light green mature or green with brown (Florinis); S6, red mature; For each chemical property of samples, the values in the columns of the table with the same letter do not differ significantly according to the Tukey's test $(\mathrm{P}=0.05), n=4$. stage (S3) decreased gradually. Furthermore, at the red maturity stage, the oblong cultivar Florinis NS 700 is characterized by a higher TP content (2220.3 $\left.\mu \mathrm{g} \mathrm{GAE} \mathrm{g}^{-1} \mathrm{FW}\right)$, compared to cultivars Dolmy F1 and Yahoo F1 that showed values 345.2 and $771.1 \mu \mathrm{g}$ GAE $\mathrm{g}^{-1} \mathrm{FW}$, respectively (Table 7). TP content in the sweet pepper cultivars Yahoo F1 and Florinis NS 700 during maturation stages showed similar results with those reported by other authors for some sweet pepper cultivars grown in India, as the cultivars Parker, Torkel, Flamingo and Golden Summer [42], and for the sweet cultivar Almuden grown in Spain [43].

NFP content in the cultivars Dolmy F1, Yahoo F1 and Florinis NS 700 during the development and maturation stages ranged from 96.66 to $194.37,121.47$ to 278.08 , and 255.72 to $466.27 \mu \mathrm{g}$ GAE g ${ }^{-1} \mathrm{FW}$, respectively (Table 7). NFP content in the sweet pepper cultivar Florinis NS 700 during development stages did not show statistically significant differences. However, the NFP content in the cultivar Yahoo F1 during development stages declined progressively by $42.08 \%$. NFP content during the maturation stages in the cultivar Dolmy F1 declined progressively by $32 \%$, while in the cultivars Yahoo F1, and Florinis NS 700 increased progressively from the green to the full red stage by $77.8 \%$ and $82.3 \%$, respectively. In addition, at the red maturity stage the sweet cultivar Florinis NS 700 is characterized by the higher NFP content $\left(466.3 \mu \mathrm{g} \mathrm{GAE} \mathrm{g}^{-1} \mathrm{FW}\right)$, compared to cultivars Dolmy F1 and Yahoo F1, which showed values 96.7 and $215.9 \mu \mathrm{g} \mathrm{GAE} \mathrm{g}^{-1} \mathrm{FW}$, respectively. The NFP fraction consists mainly dihydroxybenzoic acid and cinnamic acid derivatives [44].

FP content in the sweet pepper cultivars Dolmy F1, Yahoo F1, and Florinis NS 700 during development and maturation stages ranged by 248.5 to $403.4,283.4$ to 555.2, and 493.3 to $1754.0 \mu \mathrm{g} \mathrm{GAE} \mathrm{g}^{-1} \mathrm{FW}$, respectively. FP content in cultivar Dolmy E1 did not show statistically significant differences, during maturity stages. The FP content in the cultivar Yahoo F1 during development stages decreased gradually, while during maturation stages increased progressively (from the green to the red stage) by $95.9 \%$. FP content in cultivar Florinis NS 700 during development (S1-S2) stages did not show statistically significant differences, while during maturation stages increased progressively by $166.7 \%$. Flavonoid composition in pepper fruits varies throughout growth and ripening. Flavonoid phenols are in general synthesized during the early fruit development stages [45]. Furthermore, at the red maturity stage, the cultivar Florinis NS 700 is characterized by the highest FP content (1754.0 $\left.\mu \mathrm{g} \mathrm{GAE} \mathrm{g}^{-1} \mathrm{FW}\right)$, compared to 
cultivars Dolmy F1 and Yahoo F1, which showed values

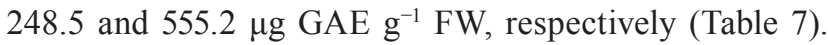
Similarly, stability in flavonoid content during maturation stages was reported for the sweet pepper cultivar Inferno grown in Texas [41]. In addition, some authors reported a decrease in FP content during maturation stages by $36 \%$ for the sweet pepper cultivar Vergasa grown in Murcia, Spain [46]. Flavonoid loss during maturation may reflect metabolic conversion to secondary phenolic compounds or degradation via enzyme action [47].

AA content in the sweet pepper cultivars Dolmy F1, Yahoo F1 and Florinis NS 700 during development and maturation stages ranged from 236 to 957,258 to 1157 , and 410 to $1550 \mu \mathrm{g} \mathrm{AA} \mathrm{g}{ }^{-1} \mathrm{FW}$, respectively (Table 7). The AA content in the cultivars Dolmy F1 and Yahoo F1 during development stages increased progressively, while during maturation stages did not show statistically significant differences $(\mathrm{P}>0.05)$, showing generally a decreasing trend. The AA content in the cultivar Florinis NS 700, both during development and maturation stages increased progressively, this increase during the three maturity stages (from the green to the red stage) reached $29.2 \%$. However, the magnitude of the changes seems to be dependent on pepper types and cultivars. In addition, at the red maturity stage, the sweet cultivar Florinis NS 700 is characterized by the highest AA content (1550 $\left.\mu \mathrm{g} \mathrm{AA} \mathrm{g}^{-1} \mathrm{FW}\right)$, compared to cultivars Dolmy F1 and Yahoo F1, which showed values 896 and $1150 \mu \mathrm{g} \mathrm{AA} \mathrm{g}^{-1} \mathrm{FW}$, respectively. AA content in the pepper cultivars either increased or remained constant as fruit matured, confirming previous studies that reported increments of ascorbic acid content during maturation stages $[41,43,46]$. These authors found that the ascorbic acid content in the sweet pepper cultivars Vergasa, Almuden and Inferno increased by $76.8 \%, 55.8 \%$ and $50.5 \%$, respectively, during maturation stages. According to Mozafar [48], the concentration of AA in fruits is probably associated to carbohydrate metabolism, while sugar accumulations are at maximum levels in red ripe fruits [49]. Fox et al. [50] reported stability in AA content during maturation stages for the sweet pepper cultivar Robusta grown in North Florida. In contrast, some authors found that the AA content in the sweet pepper cultivars Marona, Arian and Anupam decreased by $42 \%, 13 \%$ and $10 \%$ respectively, during maturation stages $[42,51]$. AA tended to increase at the start of ripening, but then decreased gradually with the advanced ripening, most probably due to its antioxidant role, which increases with the increasing respiration rate in the climacteric fruit [52].
Changes in the antiradical activity DPPH of the sweet pepper fruit cultivars during the development and maturation stages studied are shown in Fig. 1.

From Fig. 1, the antiradical activity in the sweet pepper cultivars Dolmy F1, Yahoo F1 and Florinis NS 700 during the development and maturation stages ranged from 190 to 370,240 to 450, and 320 to $980 \mu \mathrm{mol}$ Trolox $100 \mathrm{~g}^{-1} \mathrm{FW}$, respectively. Antiradical activity in these cultivars generally showed a decreasing trend during the development stages, whereas it increased progressively during the maturation stages. The Florinis NS 700 cultivar at the red maturity stage is characterized by stronger antiradical activity, compared to the cultivars Dolmy F1 and Yahoo F1. The antioxidant activity in the pepper fruits depends on the specific influence exerted by each one of their single components of the phenolic compounds and the synergy between of the individual compounds. Also, the different composition in each one of their single components during development and maturation stages of pepper fruits modifies the antioxidant activity. Our results are similar to those of other works for the sweet pepper cultivars Arian, Marona and Zorro grown at the province Rasht in Iran, reporting an increase of $7-24 \%$ in antioxidant activity during the maturation stages [51], and for the cultivars Inferno and Yellow Bell 47 grown in Texas [41].

A linear regression analysis was performed to determine the correlation between TP, NFP, FP, AA content and antiradical activity in the various pepper cultivars during the development and maturation stages and the results are presented in Table 8 . The correlation

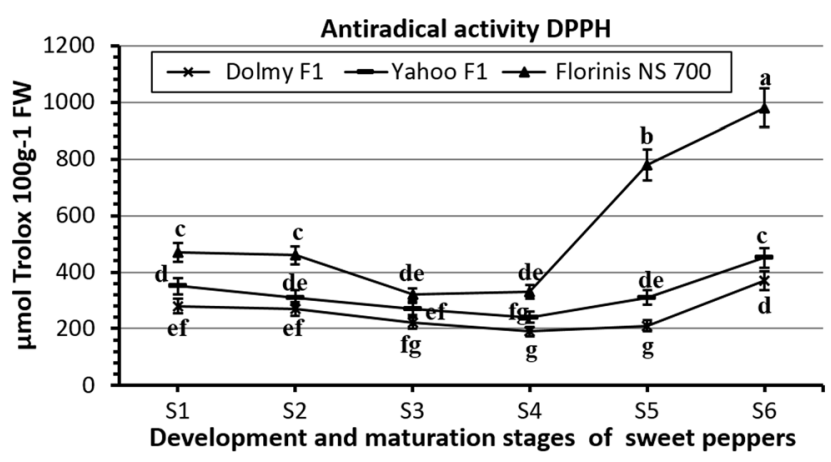

Fig. 1 Mean values and SE deviation, $(n)=4$ of antiradical activity measured during development (S1-S3) and maturation (S4-S6) stages of the sweet pepper fruits; S1, small green size; S2, medium green; S3, large green; S4, dark green mature; S5, light green mature or green with brown (Florinis); S6, red mature; Characteristics of the graph labeled with the same letter do not differ significantly according to the Tukey's test $(\mathrm{P}=0.05)$. 
analysis showed a contradictory relationship between TP content and DPPH among the different cultivars. In particular, insignificant correlation $\left(R^{2}=0.12\right)$ was observed between TP content and DPPH in the Dolmy F1 variety during development and maturation stages. The moderate correlation $\left(R^{2}=0.71\right)$ observed between of TP content and DPPH for the Yahoo F1 cultivar during development and maturation stages could be attributed to large variations in antioxidant composition between the different development and maturation stages. While, the high correlation $\left(R^{2}=0.94\right)$ observed between TP content and DPPH for the Florinis NS 700 cultivar during development and maturation stages may possibly be attributed to high polyphenolic content. Studies suggest that pepper cultivars with high polyphenolic content also have high antiradical activity [41]. The literature reports concerning the correlation of phenols and antioxidant activity are contradictory among the different pepper cultivars [41, 53]. Furthermore, the analysis showed insignificant correlation $\left(R^{2}=0.14\right)$ between AA content and DPPH for all cultivars studied, during development and maturation.

The inhibition percentage DPPH of the ethanol extracts at different stages of development and maturation of sweet peppers were examined at different concentrations of sample (100, 200, 300, 400, 500, 600, 700 and $800 \mu \mathrm{g} \mathrm{mL} \mathrm{m}^{-1}$ ) (Fig. 2).

The $\mathrm{IC}_{50}$ values of radical scavenging activity of pepper extracts at different stages of development and maturation are presented in Fig. 3.

Radical scavenging activity varied irregularly depending on the degree of maturity. The lowest radical scavenging activity $\left(\mathrm{IC}_{50}\right.$ of $580 \mu \mathrm{g} \mathrm{mL} \mathrm{m}^{-1}$ ) of the ethanol extracts for the cultivar Dolmy F1 was found in the dark green mature stage, while the highest radical scavenging activity ( $\mathrm{IC}_{50}$ of $350 \mu \mathrm{g} \mathrm{mL}^{-1}$ ) was found in the red mature stage, showing an increase of radical scavenging activity during maturation stages by $39.7 \%$.

Table 8 Correlation coefficients between antiradical activity and TP, NFP, FP, AA contents in pepper varieties during development and maturation stages

\begin{tabular}{lcccc}
\hline $\begin{array}{l}\text { Hybrid } \\
\text { varieties }\end{array}$ & TP/DPPH & NFP/DPPH & FP/DPPH & AA/DPPH \\
\hline $\begin{array}{l}\text { Dolmy } \\
\text { F1 }\end{array}$ & Insignificant & Insignificant & Insignificant & Insignificant \\
Yahoo & 0.7131 & 0.4301 & 0.8060 & Insignificant \\
F1 & & & & \\
Florinis & 0.9445 & 0.9113 & 0.9268 & Insignificant \\
NS 700 & & & & \\
\hline
\end{tabular}
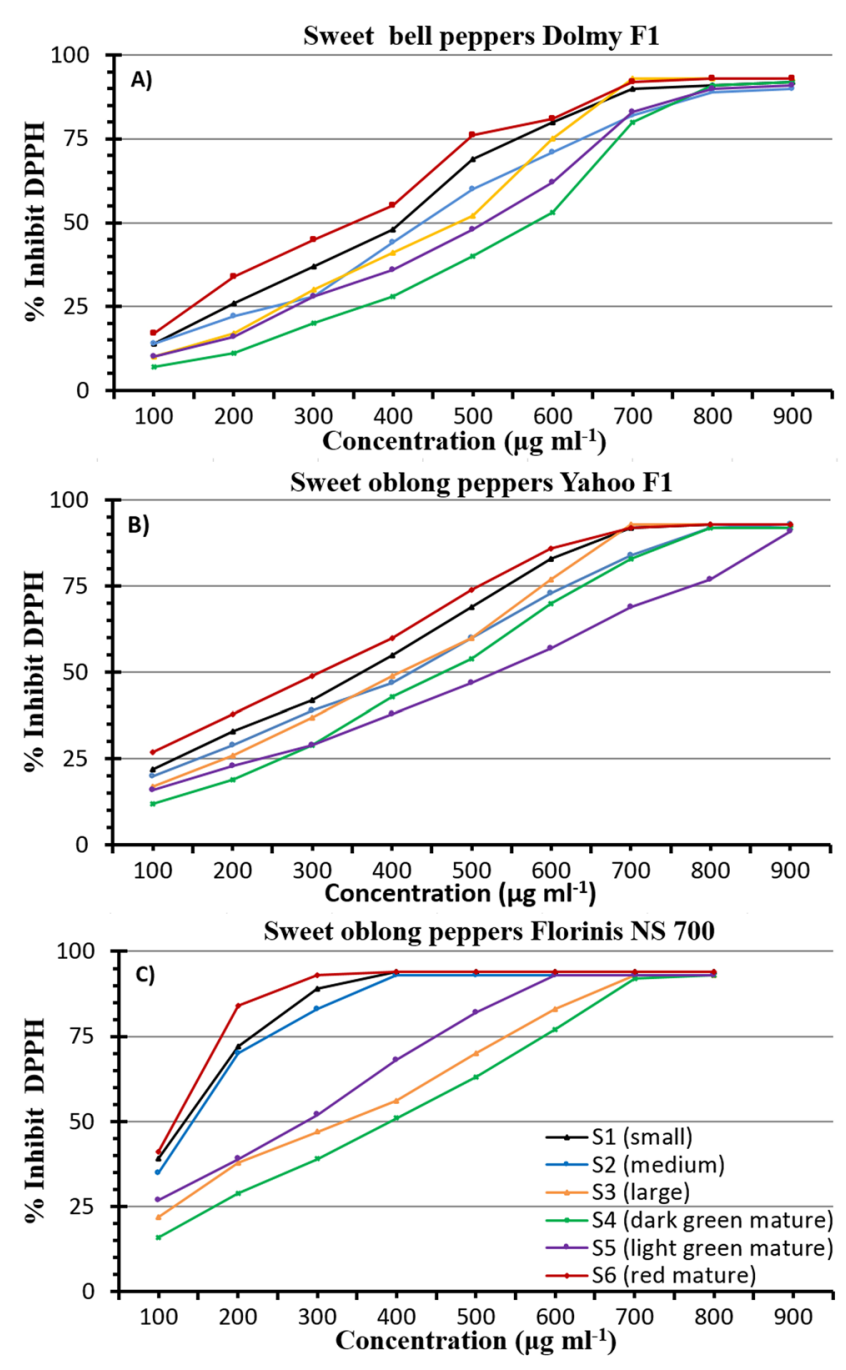

Fig. 2 Inhibition percentage DPPH as a function of different concentrations of the sample extracts during development (S1-S3) and maturation (S4-S6) stages of the sweet pepper fruits; A) variety Dolmy F1; B) variety Yahoo F1; C) variety Florinis NS 700; Data represent average, $(n)=4$.

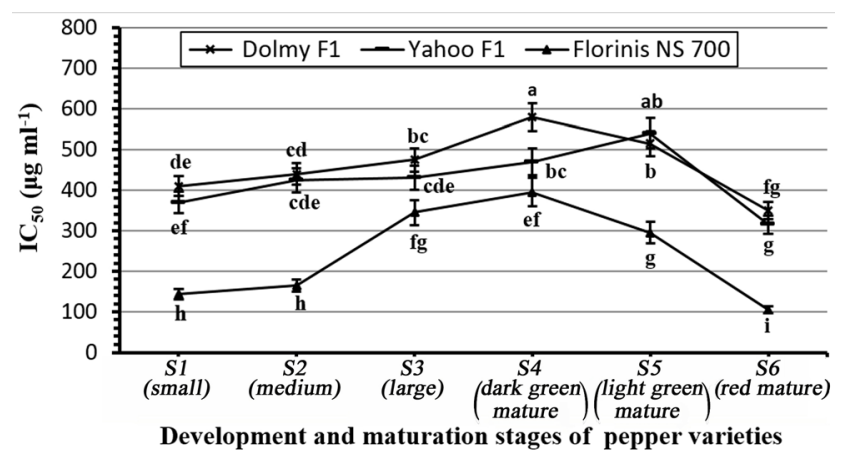

Fig. 3 Antioxidant capacity expressed by median inhibition concentration $\left(\mathrm{IC}_{50}\right)$ during development and maturation stages of the sweet pepper fruits. Characteristics of the graph labeled with the same letter do not differ significantly according to the Tukey's test $(\mathrm{P}=0.05)$. Data represent mean values and SE deviation, $(n)=4$. 
The lowest radical scavenging activity $\left(\mathrm{IC}_{50}\right.$ of $540 \mu \mathrm{g} \mathrm{mL}^{-1}$ ) for the cultivar Yahoo F1 was found in the light green mature, and the highest radical scavenging activity $\left(\mathrm{IC}_{50}\right.$ of $350 \mu \mathrm{g} \mathrm{mL}-1$ ) was found in the red maturation stage, showing an increase of radical scavenging activity during of two mature stages by $41.7 \%$.

Also, for the cultivar Florinis NS 700, the lowest radical scavenging activity $\left(\mathrm{IC}_{50}\right.$ of $395 \mu \mathrm{g} \mathrm{mL}^{-1}$ ) was found in the dark green mature stage, and the highest radical scavenging activity $\left(\mathrm{IC}_{50}\right.$ of $105 \mu \mathrm{g} \mathrm{mL^{-1 }}$ ) was found in the red mature stage, showing an increase of radical scavenging activity during maturation stages by $73.4 \%$.

The activity in the red maturation stage could be due to the higher level of phenols, the specific influence exerted by each one of their single components of the phenolic compounds and the synergy between the individual compounds. Castro-Concha et al. [54] reported the antioxidant activities of the ethanol extracts in pepper fruits Habanero at two different physiological stages: immature (25 days post-anthesis) and mature (40 days post-anthesis). The best free radical scavenging activity, increased by $45 \%$, was exerted to the mature stage $\left(\mathrm{IC}_{50}\right.$ of $71.9 \mu \mathrm{g} \mathrm{mL}^{-1}$ ) that was characterized by the highest total phenols content. In contrary, Conforti et al. [47] reported the antioxidant activities of the methanol extracts in the hot pepper fruits (Capsicum annuum var. acuminatum) at three maturity stages. At full maturity stage, fruits showed the lowest radical

\section{References}

[1] da Silveira Agostini-Costa, T., da Silva Gomes, I., Martins Palhares de Melo, L. A., Becker Reifschneider, F. J., Silva da Costa Ribeiro, C. "Carotenoid and total vitamin C content of peppers from selected Brazilian cultivars", Journal of Food Composition and Analysis, 57, pp. 73-79, 2017.

http://doi.org/10.1016/j.jfca.2016.12.020

[2] Materska, M. "Bioactive phenolics of fresh and freeze-dried sweet and semi-spicy pepper fruits (Capsicum annuum L.)", Journal of Functional Foods, 7, pp. 269-277, 2014.

https://doi.org/10.1016/j.jff.2014.02.002

[3] de Jesús Ornelas-Paz, J., Martínez-Burrola, J. M., Ruiz-Cruz, S., Santana-Rodríguez, V., Ibarra-Junquera, V., Olivas, G. I., Pérez-Martínez, J. D. "Effect of cooking on the capsaicinoids and phenolics contents of Mexican peppers", Food Chemistry, 119(4), pp. 1619-1625, 2010.

https://doi.org/10.1016/j.foodchem.2009.09.054

[4] González-Aguilar, G., Robles-Sánchez, R. M., MartínezTéllez, M. A., Olivas, G. I., Alvarez-Parrilla, E., de la Rosa, L. A. "Bioactive compounds in fruits: health benefits and effect of storage conditions", Stewart Postharvest Review, 4(3), pp. 1-10, 2008. https://doi.org/10.2212/spr.2008.3.8 scavenging activity (highest $\mathrm{IC}_{50}$ values) with an $\mathrm{IC}_{50}$ value of $429.0 \mu \mathrm{g} \mathrm{mL}^{-1}$, while at small green stage, fruits showed the highest radical scavenging activity with an $\mathrm{IC}_{50}$ value of $129 \mu \mathrm{g} \mathrm{mL}^{-1}$. The activity of small green stage could be due to the highest content of sterols and to the higher level of phenols as previously reported [55].

\section{Conclusions}

Three sweet pepper cultivars were grown in a sandy loam soil, with optimal nutrient levels and with normal levels of salinity, and were attested the corresponding effects of the fruits maturity stages on the antioxidant content (total phenols, flavonoid phenols, non-flavonoid phenols, ascorbic acid) and on the radical-scavenging activity (antioxidant capacity). The wide variations in antioxidant content among the sweet pepper cultivars and maturity stages, show that the efficacy of antioxidant compounds vary both with maturity stages as well cultivars. The study revealed that the sweet pepper cultivars Dolmy F1, Yahoo F1, and Florinis NS 700 at the red maturity stage (80 days after flowering) are a good source of mixture of antioxidant compounds including polyphenols and ascorbic acid. Finally, due to enhanced antioxidant activity at the red maturity stage, it is advisable to consume sweet pepper fruits at this stage, in order to achieve the maximum beneficial effects for the health, because of their enhanced functional properties.

[5] Gaschler, M. M., Stockwell, B. R. "Lipid peroxidation in cell death", Biochemical and Biophysical Research Communications, 482(3), pp. 419-425, 2017. https://doi.org/10.1016/j.bbrc.2016.10.086

[6] Kander, M. C., Cui, Y., Liu, Z. "Gender difference in oxidative stress: a new look at the mechanisms for cardiovascular diseases", Journal of Cellular and Molecular Medicine, 21(5), pp. 1024-1032, 2017. https://doi.org/10.1111/jcmm.13038

[7] Poprac, P., Jomova, K., Simunkova, M., Kollar, V., Rhodes, C. J., Valko, M. "Targeting Free Radicals in Oxidative Stress-Related Human Diseases", Trends in Pharmacological Sciences, 38(7), pp. 592-607, 2017. https://doi.org/10.1016/j.tips.2017.04.005

[8] Kőszegi, K., Békássy-Molnár, E., Koczka, N., Kerner, T., StefanovitsBányai, É. "Changes in Total Polyphenol Content and Antioxidant Capacity of Stinging Nettle (Urtica dioica L.) from Spring to Autumn", Periodica Polytechnica Chemical Engineering, 2019. https://doi.org/10.3311/PPch.14338

[9] Knežević, V., Pezo, L. L., Lončar, B. Lj., Filipović, V. S., Nićetin, M. R., Gorjanović, S. Ž., Šuput, D. "Antioxidant Capacity of Nettle Leaves During Osmotic Treatment", Periodica Polytechnica Chemical Engineering, 63(3), pp. 491-498, 2019. https://doi.org/10.3311/PPch.12688 
[10] Mirończuk-Chodakowska, I., Witkowska, A. M., Zujko, M. E. "Endogenous non-enzymatic antioxidants in the human body", Advances in Medical Sciences, 63(1), pp. 68-78, 2018. https://doi.org/10.1016/j.advms.2017.05.005

[11] Mancuso, C., Barone, E., Guido, P., Miceli, F., Di Domenico, F., Perluigi, M., Santangelo, R., Preziosi, P. "Inhibition of lipid peroxidation and protein oxidation by endogenous and exogenous antioxidants in rat brain microsomes in vitro", Neuroscience Letters, 518(2), pp. 101-105, 2012.

https://doi.org/10.1016/j.neulet.2012.04.062

[12] Mithöfer, A., Maffei, M. E. "General Mechanisms of Plant Defense and Plant Toxins", In: Gopalakrishnakone, P., Carlini, C., LigabueBraun, R. (eds.) Plant Toxins, Springer, Dordrecht, Netherlands, pp. 1-22, 2016.

https://doi.org/10.1007/978-94-007-6728-7_21-1

[13] Maag, D., Erb, M., Köllner, T. G., Gershenzon, J. "Defensive weapons and defense signals in plants: Some metabolites serve both roles", BioEssays, 37(2), pp. 167-174, 2015.

https://doi.org/10.1002/bies.201400124

[14] Pichersky, E., Gang, D. R. "Genetics and biochemistry of secondary metabolites in plants: an evolutionary perspective", Trends in Plant Science, 5(10), pp. 439-445, 2000.

https://doi.org/10.1016/S1360-1385(00)01741-6

[15] Croft, K. D. "Antioxidant Effects of Plant Phenolic Compounds", In: Basu, T. K., Temple, N. J., Garg, M. L. (eds.) Antioxidants in Human Health and Disease, CABI Publishing, New York, NY, USA, pp. 109-121, 1999. [online] Available at: https://epdf. pub/antioxidants-in-human-health-and-disease.html [Accessed: 24 May 2018]

[16] Riebel, M., Sabel, A., Claus, H., Xia, N., Li, H., König, H., Decker, H., Fronk, P. "Antioxidant capacity of phenolic compounds on human cell lines as affected by grape-tyrosinase and Botrytislaccase oxidation", Food Chemistry, 229, pp. 779-789, 2017. https://doi.org/10.1016/j.foodchem.2017.03.003

[17] Burda, S., Oleszek, W. "Antioxidant and Antiradical Activities of Flavonoids", Journal of Agricultural and Food Chemistry, 49(6), pp. 2774-2779, 2001. https://doi.org/10.1021/jf001413m

[18] Rice-Evans, C. A., Miller, N. J., Paganga, G. "Structureantioxidant activity relationships of flavonoids and phenolic acids", Free Radical Biology Medicine, 20(7), pp. 933-956, 1996. https://doi.org/10.1016/0891-5849(95)02227-9

[19] Manach, C., Scalbert, A., Morand, C., Rémésy, C., Jiménez, L. "Polyphenols: food sources and bioavailability", The American Journal of Clinical Nutrition, 79(5), pp. 727-747, 2004. https://oi.org/10.1093/ajen/79.5.727

[20] Ferrari, C. K. B., Torres, E. A. F. S. "Biochemical pharmacology of functional foods and prevention of chronic diseases of aging", Biomedicine \& Pharmacotherapy, 57(5-6), pp. 251-260, 2003. https://doi.org/10.1016/S0753-3322(03)00032-5

[21] Ayodele, O. J., Alabi, E. O., Aluko, M. "Nitrogen Fertilizer Effects on Growth, Yield and Chemical Composition of Hot Pepper (Rodo)", International Journal of Agriculture and Crop Sciences, 8(5), pp. 666-673, 2015. [online] Available at: http://www.ijagcs. com [Accessed: 08 May 2018]
[22] Bae, H., Jayaprakasha, G. K., Crosby, K., Yoo, K. S., Leskovar, D. I., Jifon, J., Patil, B. S. "Ascorbic acid, capsaicinoid, and flavonoid aglycone concentrations as a function of fruit maturity stage in greenhouse-grown peppers", Journal of Food Composition and Analysis, 33(2), pp. 195-202, 2014.

https://doi.org/10.1016/j.jfca.2013.11.009

[23] Baath, G. S., Shukla, M. K., Bosland, P. W., Steiner, R. L., Walker, S. J. "Irrigation water salinity influences at various growth stages of Capsicum annuum", Agricultural Water Management, 179, pp. 246-253, 2017.

https://doi.org/10.1016/j.agwat.2016.05.028

[24] Azuma, R., Ito, N., Nakayama, N., Suwa, R., Nguyen, N. T., Larrinaga-Mayoral, J. Á., Esaka, M., Fujiyama, H., Saneoka, H. "Fruits are more sensitive to salinity than leaves and stems in pepper plants (Capsicum annuиm L.)", Scientia Horticulturae, 125(3), pp. 171-178, 2010. https://doi.org/10.1016/j.scienta.2010.04.006

[25] Navarro, J. M., Flores, P., Garrido, C., Martinez, V. "Changes in the contents of antioxidant compounds in pepper fruits at different ripening stages, as affected by salinity", Food Chemistry, 96(1), pp. 66-73, 2006.

https://doi.org/10.1016/j.foodchem.2005.01.057

[26] Piazzolla, F., Amodio, M. L., Rinaldi, R., Raimo, F., Colelli, G. "Effect of type of fertilization and maturity on quality of freshcut red and yellow peppers (Capsicum annuиm L.)", Advances in Horticultural Science, 26(2), pp. 81-87, 2012.

https://doi.org/10.13128/ahs-12741

[27] Lee, S. K., Kader, A. A. "Preharvest and postharvest factors influencing vitamin C content of horticultural crops", Postharvest Biology and Technology, 20(3), pp. 207-220, 2000. https://doi.org/10.1016/S0925-5214(00)00133-2

[28] Page, A. L. "Methods of soil analysis, Part 2: Chemical and microbiological properties", American Society of Agronomy, Soil Science Society of America, Madison, WI, USA, 1982. [online] Available at: https://acsess.onlinelibrary.wiley.com/doi/pdf/10.2134/ agronmonogr9.2.2ed.frontmatter [Accessed: 01 February 2018]

[29] Varian "Flame Atomic Absorption Spectroscopy", Analytical Methods, Publ. No: 85-100009-00, Varian Techtron Pty. Ltd. Springvale, Australia, 1989. [online] Available at: https://www. agilent.com/cs/library/usermanuals/Public/0009.pdf [Accessed: 17 May 2018]

[30] Jones Jr, J. B. "Plant nutritional manual", CRC Press, Boca Raton, FL, USA, 1998.

[31] Jones Jr, J. B., Case, V. W. "Sampling, Handling and Analyzing Plant Tissue Samples", In: Westerman, R. L. (ed.) Soil Testing and Plant Analysis, Soil Science Society of America, Madison, WI, USA, pp. 389-427, 1990.

https://doi.org/10.2136/sssabookser3.3ed.c15

[32] Kanner, J., Frankel, E., Granit, R., German, B., Kinsella, J. E. "Natural antioxidants in grapes and wines", Journal of Agricultural and Food Chemistry, 42(1), pp. 64-69, 1994. https://doi.org/10.1021/jf00037a010

[33] Tubaro, F., Pizzuto, R., Raimo, G., Paventi, G. "A Novel Fluorimetric Method to Evaluate Red Wine Antioxidant Activity", Periodica Polytechnica Chemical Engineering, 63(1), pp. 57-64, 2019. https://doi.org/10.3311/PPch.12192 
[34] Singleton, V. L., Rossi, J. A. "Colorimetry of Total Phenolics with Phosphomolybdic-Phosphotungstic Acid Reagents", American Journal of Enology and Viticulture, 16(3), pp. 144-158, 1965. [online] Available at: https://www.ajevonline.org/content/16/3/144 [Accessed: 17 January 2019]

[35] Baderschneider, B., Luthria, D., Waterhouse, A. L., Winterhalter, P. "Antioxidants in white wine (cv. Riesling): I. Comparison of different testing methods for antioxidant activity", Vitis, 38(3), pp. 127-131, 1999. https://doi.org/10.5073/vitis.1999.38.127-131

[36] Kramling, T. E., Singleton, V. L. "An Estimate of the Nonflavonoid Phenols in Wines", American Journal of Enology and Viticulture, 20(2), pp. 86-92, 1969. [online] Available at: https://www.ajevonline.org/content/20/2/86 [Accessed: 10 January 2019]

[37] Deepa, N., Kaur, C., Singh, B., Kapoor, H. C. "Antioxidant activity in some red sweet pepper cultivars", Journal of Food Composition and Analysis, 19(6-7), pp. 572-578, 2006. https://doi.org/10.1016/j.jfca.2005.03.005

[38] Brand-Williams, W., Cuvelier, M. E., Berset, C. "Use of a free radical method to evaluate antioxidant activity", LWT - Food Science and Technology, 28(1), pp. 25-30, 1995. https://doi.org/10.1016/S0023-6438(95)80008-5

[39] Yen, G. C., Duh, P. D. "Scavenging Effect of Methanolic Extracts of Peanut Hulls on Free-Radical and Active-Oxygen Species", Journal of Agricultural and Food Chemistry, 42(3), pp. 629-632, 1994. https://doi.org/10.1021/jf00039a005

[40] Ryan, B. F., Joiner, B. L., Cryer, J. D. "MINITAB Handbook: Updated for release 14", Pacific Grove, Duxbury, CA, USA, 2005.

[41] Howard, L. R., Talcott, S. T., Brenes, C. H., Villalon, B. "Changes in Phytochemical and Antioxidant Activity of Selected Pepper Cultivars (Capsicum Species) As Influenced by Maturity", Journal of Agricultural and Food Chemistry, 48(5), pp. 1713-1720, 2000. https://doi.org/10.1021/jf990916t

[42] Deepa, N., Kaur, C., George, B., Singh, B., Kapoor, H. C. "Antioxidant constituents in some sweet pepper (Capsicum annuum L.) genotypes during maturity", LWT - Food Science and Technology, 40(1), pp. 121-129, 2007. https://doi.org/10.1016/j.lwt.2005.09.016

[43] Pérez-López, A. J., del Amor, F. M., Serrano-Martinez, A., Fortea, M. I., Núñez-Delicado, E. "Influence of agricultural practices on the quality of sweet pepper fruits as affected by the maturity stage", Journal of the Science of Food and Agriculture, 87(11), pp. 2075-2080, 2007. https://doi.org/10.1002/jsfa.2966

[44] Zhuang, Y., Chen, L., Sun, L., Cao, J. "Bioactive characteristics and antioxidant activities of nine peppers", Journal of Functional Foods, 4(1), pp. 331-338, 2012. https://doi.org/10.1016/j.jff.2012.01.001

[45] Ageorges, A., Cheynier, V., Terrier, N. "Polyphenols", In: Nath, P., Bouzayen, M., Mattoo, A. K., Pech, J. C. (eds.) Fruit Ripening: Physiology, Signalling and Genomics, CABI, Wallingford, UK, pp. 151-177, 2014.

https://doi.org/10.1079/9781845939625.0151
[46] Marín, A., Ferreres, F., Tomás-Barberán, F. A., Gil, M. I. "Characterization and Quantitation of Antioxidant Constituents of Sweet Pepper (Capsicum annuum L.)", Journal of Agricultural and Food Chemistry, 52(12), pp. 3861-3869, 2004.

https://doi.org/10.1021/jf0497915

[47] Conforti, F., Statti, G. A., Menichini, F. "Chemical and biological variability of hot pepper fruits (Capsicum аппиит var. acuminatum L.) in relation to maturity stage", Food Chemistry, 102(4), pp. 1096-1104, 2007.

https://doi.org/10.1016/j.foodchem.2006.06.047

[48] Mozafar, A. "Plant Vitamins: Agronomic, Physiological and Nutritional Aspects", CRC Press, Boca Raton, FL, 1994. https://doi.org/10.1201/9781351075800

[49] Osuna-García, J. A., Wall, M. M., Waddell, C. A. "Endogenous Levels of Tocopherols and Ascorbic Acid during Fruit Ripening of New Mexican-Type Chile (Capsicum annuиm L.) Cultivars", Journal of Agricultural and Food Chemistry, 46(12), pp. 5093-5096, 1998.

https://doi.org/10.1021/jf980588h

[50] Fox, A. J., Del Pozo-Insfran, D., Lee, J. H., Sargent, S. A., Talcott, S. T. "Ripening-induced Chemical and Antioxidant Changes in Bell Peppers as Affected by Harvest Maturity and Postharvest Ethylene Exposure", HortScience, 40(3), pp. 732-736, 2005. https://doi.org/10.21273/HORTSCI.40.3.732

[51] Ghasemnezhad, M., Sherafati, M., Payvast, G. A. "Variation in phenolic compounds, ascorbic acid and antioxidant activity of five coloured bell pepper (Capsicum annum) fruits at two different harvest times", Journal of Functional Foods, 3(1), pp. 44-49, 2011. https://doi.org/10.1016/j.jff.2011.02.002

[52] Márkus, F., Daood, H. G., Kapitány, J., Biacs, P. A. "Change in the Carotenoid and Antioxidant Content of Spice Red Pepper (paprika) as a Function of Ripening and Some Technological Factors", Journal of Agricultural and Food Chemistry, 47(1), pp. 100-107, 1999. https://doi.org/10.1021/jf980485z

[53] Imeh, U., Khokhar, S. "Distribution of Conjugated and Free Phenols in Fruits: Antioxidant Activity and Cultivar Variations", Journal of Agricultural and Food Chemistry, 50(22), pp. 6301-6306, 2002. https://doi.org/10.1021/jf020342j

[54] Castro-Concha, L. A., Tuyub-Che, J., Moo-Mukul, A., VazquezFlota, F. A., Miranda-Ham, M. L. "Antioxidant Capacity and Total Phenolic Content in Fruit Tissues from Accessions of Capsicum chinense Jacq. (Habanero Pepper) at Different Stages of Ripening", The Scientific World Journal, 2014, Article ID: 809073, 2014. https://doi.org/10.1155/2014/809073

[55] Yoshida, Y., Niki, E. "Antioxidant Effects of Phytosterol and Its Components", Journal of Nutritional Science and Vitaminology, 49(4), pp. 277-280, 2003. https://doi.org/10.3177/jnsv.49.277 